\title{
Contextualized E-Learning Resource: A Tool for Stronger Academic Platform
}

\author{
E. C. Jimenez \\ Education Program Supervisor, Department of Education, Division of City of Meycauayan, \\ Bulacan, Philippines \\ E-Mail: edward.jimenez@deped.gov.ph
}

Area of the Paper: Education Management.

Type of the Paper: Conceptual Research.

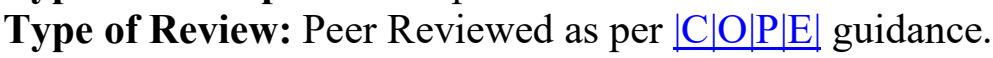

Indexed In: OpenAIRE.

DOI: http://doi.org/10.5281/zenodo.4018344.

Google Scholar Citation: IJCSBE.

\section{How to Cite this Paper:}

Jimenez, E. C. (2020). Contextualized E-Learning Resource: A Tool for Stronger Academic Platform. International Journal of Case Studies in Business, IT, and Education (IJCSBE), 4(2), 110-116. DOI: http://doi.org/10.5281/zenodo.4018344.

International Journal of Case Studies in Business, IT and Education (IJCSBE)

A Refereed International Journal of Srinivas University, India.

(C) With Authors.

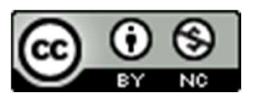

This work is licensed under a Creative Commons Attribution Non-Commercial 4.0 International License subject to proper citation to the publication source of the work.

Disclaimer: The scholarly papers as reviewed and published by the Srinivas Publications (S.P.), India are the views and opinions of their respective authors and are not the views or opinions of the S.P. The S.P. disclaims of any harm or loss caused due to the published content to any party. 


\title{
Contextualized E-Learning Resource: A Tool for Stronger Academic Platform
}

\author{
E. C. Jimenez \\ Education Program Supervisor, Department of Education, Division of City of Meycauayan, \\ Bulacan, Philippines \\ E-Mail: edward.jimenez@,deped.gov.ph
}

\begin{abstract}
This aim of this study was conducted to recognize the impact of contextualized e-learning resources as tools for a stronger academic platform. To achieve this, this paper used an experimental type of research. A total of 180 students participated in the experiment using cluster sampling. For the instrument, this study used Supplementary Learning Resources (Digital Flipbook). A paired sample t-test was used to assess the significant effect of the contextualized e-learning resource to the academic performance of the students. The result of the experiment showed no significant difference between the means pre-test scores of the two groups. But upon the utilization of contextualized e-Learning Materials, it showed that the pvalue of the post-test scores is less than the alpha significance level 0.05 . This means that the use of contextualized e-Learning Resources in teaching Mathematics in grade 3 learners has a significant effect to increase learners' academic performance. This also proved that the use of contextualized e-Learning Resources increases the academic performance of learners. The electronic tools provided by the teacher created a sound learning environment to master the least learned competencies. In light of the conclusion drawn, the researcher recommended pertinent suggestions that are deemed beneficial for the teachers and heads of institutions.
\end{abstract}

Keywords: Contextualization, E-Learning Resources, Academic Performance, Grade 3 Mathematics, Academic Platform.

\section{INTRODUCTION :}

Supplementary Learning Materials are substantial tools for delivering lessons of teachers to the learners. Teachers are the best developers of these supplementary learning materials. They have the best capacity to develop a set of well-fit instructional materials for the learners to attain the mastery of learning competencies. In a related paper, it indicated that the development of supplementary learning materials is an initiative that motivates teachers for promotion [1]. Besides, another study specified that the teacher's enthusiasm and skills in advancing digital classroom models increases [2]. Because of this idea, the work attitudes of teachers were very high [3] and this leads to professionalism and satisfaction in the organization [4]. Contextualized instructional materials or supplementary learning materials through the use of technology enable the learners to pave the way the mastery of the different competencies which are very essential for education and learning. A paper highlighted the importance of integrating knowledge and communication technologies in teaching and learning Mathematics [5]. A development study [6] done by a team of researchers showed a promising solution for grooming teachers to carry out the curriculum by using an android-based e-tutorial material. Also, a high level of completeness of learning design in Mathematics is due to students studying independently through materials uploaded by the lecturer [7]. According to another related study, it revealed that ICT resources impact teaching and learning [8]. This concretizes that utilization of digitizes contextualized learning materials developed and produced by the teachers.

Electronic Learning Resources (e-LRs) provide avenues to learners to be familiarized with the different competencies which have activities that are all Higher Order Thinking Skills (HOTS), interactive and friendly. The use of localized materials and information brings a closer look at the necessities of the learners to promote locality where they belong. Relative to this, another paper argued that non- 


\section{International Journal of Case Studies in Business, IT, and Education SRINIVAS (IJCSBE), ISSN: 2581-6942, Vol. 4, No. 2, September 2020. \\ PUBLICATION}

traditional teaching in mathematics is completed using a problem-solving method where the student is the problem solver [9]. To add, another group of investigators identified some educational challenges and provided potential possibilities for e-learning [10]. Likewise, indigenized learning resources to learners unable to contact the different groups of people within the local setting where norms, biographies, customs, and traditions are imposed to be enjoined and respected. Teaching and learning become more eminent and domain, if the knowledge acquires and learn by the learners to the teachers, are reliable and credible. As promoted by some researchers, the teacher has very good professional skills [11]. Students in higher education also described how an educator is well-qualified [12]. This emphasizes the theory of Constructivist by Jerome Bruner which explains how people might obtain information and recognize them. Furthermore, the theory also proposed that individuals create ideas and connotation from their involvements. For example, a study considered problem-based learning as a useful strategy to progress student's critical thinking skills [13]. In relation, another study stipulated that discovery, exposition, and traditional methods of teaching improve the problem-solving abilities of students [14]. Besides, a group of researchers also showed that blended learning experiences benefitted students [15]. And this theory complements this study that the use of personal experiences, inspiration, and local resources provide credible knowledge and local history. As far as instruction is concerned, teachers should deliver the lesson well and try and encourage the learners to discover learning from themselves through the help of contextualized learning resources. This is a skill intended for the $21^{\text {st }}$-century learners that teachers need to master to make them a well-qualified educator [16] [17]. Thus, teachers should translate information to the learners in the most appropriate and suited way based on the learners' state of understanding. It is evitable that the curriculum as well should be contextualized to promote mastery of learning competencies.

This study aims to give light on the impact of contextualized e-learning resources as tools for increasing learners' performance. This paper is limited to the teachers of the Schools Division of City of Meycauayan for the school year 2019 - 2020. This action research paper utilized the experimental method of research design, which aide in quantifying and qualifying results of the study and equating the results to psychological and behavioral facts. The study also considered the inherent factors of the respondents to determine the impact of contextualized e-learning resources as tools for a stronger academic platform.

\section{RESEARCH QUESTIONS :}

This action research wanted to identify the impact of contextualized e-learning resources as a tool for a stronger academic platform among Grade 3 students in their Mathematics subject. Specifically, it sought to answers the following queries:

a) Is there a significant difference in the performance level of the grade 3 learners in Mathematics before and after the use of contextualized e-learning resources?

b) Is there a significant effect of the contextualized e-learning resources of the elementary grade 3 learners on their academic performance?

\section{METHODOLOGY :}

\subsection{Research Design}

Since the main concern of the study was to recognize the impact of contextualized e-learning resources as tools in increasing learners' academic performance, this study used an experimental type of research. Information and data were gathered through a survey questionnaire, interview, and personal observations. The data gathered was tabulated and subjected to statistical treatment for proper analysis and interpretations.

\subsection{Respondents}

The participants of this study were the three (3) elementary teachers and one hundred eighty (180) learners in Clusters A, B, and C of the twenty-five (25) elementary schools in the Schools Division of City of Meycauayan for the school year $2019-2020$.

Table 1 : Respondents of the Study

\section{Cluster}

Name of School
Number of Participants 


\begin{tabular}{|c|c|c|}
\hline A & Iba Elementary School & 60 \\
\hline B & Bancal Integrated School & 60 \\
\hline C & Calvario Elementary School & 60 \\
\hline
\end{tabular}

\subsection{Instrument of the Study}

This particular action research made use of Supplementary Learning Resources (Digital Flipbook). Flipbook is a digitized material that uses technological specifications and skills of teachers on their developed lessons with audible tonal voices of characters. Flipbook promotes learners' interactive participation because it uses different languages or the Mother Tongue Based-Multilingual Education (MTB-MLE) based on the locality of the school. It passed the Quality Assurance and validation process of the Learning Resource Evaluators.

\subsection{Data Collection Procedure}

The researcher submitted the letter of request to the Chairpersons of Cluster School Heads regarding the conduct of the study. Upon retrieving the approved letter of request, the Chairperson Cluster School Heads were asked to give one (1) teacher and two (2) heterogeneous class in Grade 3 who represented the entire population of the cluster. Respondents used contextualized supplementary e-learning materials (SLMs) in the delivery of the lessons. The gathered data was tabulated using Microsoft Excel and statistically analyzed using SPSS 20.

\subsection{Data Analysis}

This research employed the t-test data analysis to best describe the significant effect of two groups using a pretest-posttest process. The raw scores in the pretest of the control group were compared and analyzed using a paired t-test. Similarly, the raw scores for the posttest of the experimental group were also examined and found out significantly different.

The data gathered was tabulated and subjected to statistical treatment for proper analysis and interpretation. The following statistical tools will be used: weighted mean, standard deviation, and a paired sample t-test.

\section{RESULTS :}

This particular action research aimed to evaluate the effect of contextualized e-learning resources as tools for increasing learners' performance. With the use of statistical inference, the following results were presented.

Table 2: Learners' Performance before the Use of e-Learning Resources

\begin{tabular}{|l|c|c|c|c|c|}
\hline & $\mathrm{N}$ & Mean & SD & t-test & Sig. \\
\hline Experimental Group & 90 & 3.68 & 1.17 & -1.926 & .057 \\
\hline Control Group & 90 & 3.81 & 1.19 & & \\
\hline
\end{tabular}

$$
d f=89 ; p>.05
$$

Table 1 showed the result of the learner's performance before the use of e-learning resources. As seen, there was no significant difference between the experimental group $(\mathrm{M}=3.68 ; \mathrm{SD}=1.17)$ and the control group $(\mathrm{M}=3.81 ; \mathrm{SD}=1.19)$ scores. This is so since $t(89)=-1.926, p=.057$ wherein the $p$-value is higher than the alpha significance level of .05.

Table 3: Learners' Performance after the Use of e-Learning Resources

\begin{tabular}{|l|c|c|c|c|c|}
\hline & $\mathrm{N}$ & Mean & SD & t-test & Sig. \\
\hline Experimental Group & 90 & 3.54 & 1.72 & $6.551^{*}$ & .000 \\
\hline Control Group & 90 & 2.46 & 1.56 & & \\
\hline
\end{tabular}

$$
d f=89 ; * p<.05
$$

Table 2 showed the result of the learner's performance after the use of e-learning resources. As observed, there was a significant difference between the experimental group's score $(\mathrm{M}=3.54 ; \mathrm{SD}=$ $1.72)$ and the control group's score $(\mathrm{M}=2.46 ; \mathrm{SD}=1.56)$. Furthermore, the analysis also showed $t(89)=$ 


\section{International Journal of Case Studies in Business, IT, and Education SRINIVAS (IJCSBE), ISSN: 2581-6942, Vol. 4, No. 2, September 2020.

$6.551, p=.000$, where the $p$-value is lower than the alpha significance value of .05 . This showed evidence that there is a significant change in the scores of the contrasted groups.

Table 4: Learner's Overall Performance

\begin{tabular}{|l|c|c|c|c|c|}
\hline & $\mathrm{N}$ & Mean & SD & t-test & Sig. \\
\hline Experimental Group & 90 & 7.49 & 2.26 & $4.331^{*}$ & .000 \\
\hline Control Group & 90 & 6.00 & 2.89 & & \\
\hline
\end{tabular}

$d f=89 ; * p<.05$

Table 3 showed the overall performance of the learner's pre-test and post-test total scores. As seen, there was a significant difference in the scores between the experimental group's total scores $(M=7.49$; $\mathrm{SD}=2.26)$ and the control group's score $(\mathrm{M}=6.00 ; \mathrm{SD}=2.89)$. At the same time, the table also showed that $t(89)=4.331, p=.000$, which is significant at .05 alpha significance level. Specifically, the mean post-test scores of the learners in the experimental group are higher than that of the pupils in the control group. This finding implies that the teaching tool is effective for improving learners' academic performance in Mathematics 3.

\section{DISCUSSIONS :}

Based on the research conducted, the result of the t-test before the administration of the material yielded -1.926 with a probability value of is 0.057 . The product is greater than the .05 alpha level of significance. Therefore, it is concluded that there is no significant difference between the means pre-test scores of the two groups. But upon the used of contextualized e-Learning Materials, it showed that the p-value from the t-test Two Sample for Variance of the post-test scores is .000 and that is less than 0.05 which means that the use of contextualized e-Learning Resources in teaching Mathematics in grade 3 learners has significant effect to increase learners' academic performance based from t-test. This proves the significant effect on the use of contextualized e-Learning Resources increases the academic performance of learners. The electronic tools provided by the teacher created a sound learning environment to master the least learned competencies

The result of the research conducted proves the significant impact of remediation activities on the academic performance of grade 3 learners as shown in table 3 with a $t$-value of .000 . This means that there is a significant effect brought about using contextualized e-Learning Resources. This was strengthened by a study wherein it stressed that there is no one size-fits-all of doing things-what is operative and fitting teaching [18]. It changes to a great degree on an extensive diversity of contextual factors that play an important role in determining the extent to which teachers can execute instruction similar with the learner's cognition. On the other hand, another paper showed that remediation intervention activities significantly improve students' academic performance [19]. It was also supported by another study conducted by a group of researchers which emphasized that e-learning tools can represent an effective way of supporting this new trend in education [20]. To add, another study showed that using information and communication technology (ICT) is effective in improving students' mathematical reasoning skills [21]. Furthermore, a related study also proposed that e-learning's effectiveness is heightened by building efficient infrastructure, unceasing standardization efforts [22].

\section{CONCLUSION :}

This study aimed to determine whether contextualized e-learning resource is beneficial to the academic works of learners. The study found, based on the findings, a significant difference in the pretest and posttest scores of the pupils. The experimental group yielded a higher mean score than the control group. This proves that the instructional method provided evidence of improvement in the learners' academic performance in the subject of Mathematics in the classroom.

\section{RECOMMENDATIONS :}

Grounded on the conclusion extracted, the following recommendations are offered by the investigator:

1. Teachers should have the courage to continuously develop contextualized e-Learning Resources that will help every learner to master different learning competencies; 
2. All teachers should adopt the use of electronic Learning Resources to deliver the lessons and most importantly, bridge the least learned competencies of all subject areas to improve learners' output;

3. Teachers should religiously be present to training and seminars regarding technological competence that will promote better teaching and interactive learning among teachers and learners;

4. School heads should include through SLAC or INSET the development of contextualized electronic media in the schools for the development and improvement of learning and to raise the higher academic performance of learners in all subjects;

5. School heads may tap the potential of school ICT Coordinators, Illustrators and Layout Artists with the assistance of School LR Coordinators who are capacitated in the latest software applications to promote collaboration of interactive multimedia materials in all subjects; and

6. Education Program Supervisors may utilize this study as a springboard in the development of their programs and acclimatize to this strategy for the advancement of a higher academic prospects in their respective areas.

\section{REFERENCES :}

[1] Jimenez, E.C. (2020). Motivating factors of teachers in developing supplementary learning materials (SLMs). International Journal of Advanced Research, 8(5), 108-113. https://dx.doi.org/10.21474/IJAR01/10912.

[2] Helsa, Y., Ariani, Y., \& Kenedi, A.K. (2019). Digital class model in Mathematics learning in elementary school using social learning network Schoology. Advances in Social Science, Education and Humanities Research, 382, 739-742. https://doi.org/10.2991/icet-19.2019.177.

[3] Jimenez, E.C. (2020). Emotional quotient, work attitude, and teaching performance of secondary school teachers. Journal of Pedagogical Sociology and Psychology, 2(1), 25-35. https://doi.org/10.33902/JPSP.2020161079.

[4] Asio, J.M.R., \& Jimenez, E.C. (2020). Professional development, organizational climate, supervisory rapport, and overall satisfaction of employees: An attitudinal study. International Journal of Scientific Research in Multidisciplinary Studies, 6(4), 34-40. https://doi.org/10.6084/m9.figshare.12698195.v2.

[5] Das, K. (2019). Role of ICT for better Mathematics teaching. Shanlax International Journal of Education, 7(4), 19-28. https://doi.org/10.34293/education.v7i4.641.

[6] Roza Y., Daqiqil I., Siregar, S.N., Salam, S., \& Adnan, A. (2018). Android-based e-learning tutorial for Mathematics teachers. Journal of Physics: Conference Series, 1088, 012005. https://doi.org/10.1088/1742-6596/10088/012005.

[7] Sulistyaningsih, D., Purnomo, \& Aziz, A. (2019). Development of learning design for Mathematics manipulatives learning based on e-learning and character building. International Electronic Journal of Mathematics Education, 14(1), 197-205. https://doi.org/10.29333/iejme/3996.

[8] Adeyemo, S.A. (2010). The impact of information and communication technology (ICT) on teaching and learning Physics. International Journal of Educational Research and Technology, 1 (2), 6-8.

[9] Tularam, G.A., \& Machisella, P. (2018). Traditional vs non-traditional teaching and learning strategies-the case of e-learning! International Journal for Mathematics Teaching and Learning, 19(1), 129-158. https://cimt.org.uk/ijmtl/index.php/IJMTL/article/view/21.

[10] Musiimenta, A., Tumuhimbise, W., Nankunda, M., Bangumya, E., Atuhaire, J., Mugonza, R., Kobutungi, P., \& Mugaba, A.T. (2019). Electronic learning may improve the teaching and learning of mathematics and science in marginalized schools in Nakivale refugee settlement, Uganda: A 
baseline analysis. Journal of Education and Development, 3(2), 63-72. https://doi.org/10.20849/jed.v3i2.611.

[11] Asio, J.M.R., Riego de Dios, E.E., \& Lapuz, A.M.E. (2019). Professional skills and work ethics of selected faculty in a local college. PAFTE Research Journal, 9(1), 164-180. https://doi.org/10.5281/zenodo.3980627.

[12] Asio, J.M.R., \& Riego de Dios, E.E. (2019). The college students' perspective on what makes an educator well-qualified. Journal of Pedagogical Research, 3(3), 126-138. https://doi.org/10.33902/jpr.v3i3.124.

[13] Lapuz, A.M.E. \& Fulgencio, M.N. (2020). Improving critical thinking skills of secondary school students using problem-based learning. International Journal of Academic Multidisciplinary Research, 4(1), 1-7. https://ssrn.com/abstract=3543211.

[14] Jimenez, E.C. (2020). Problem-solving ability of first-year high school students in Mathematics as affected by cognitive development levels and teaching strategies. Instabright e-Gazette, 1(3), 122. http://dx.doi.org/10.2139/ssrn.3530765.

[15] Lin, Y.-W., Tseng, C.-L., \& Chiang, P.-J. (2017). The effect of blended learning in Mathematics courses. EURASIA Journal of Mathematics, Science and Technology Education, 13 (3), 741-770. https://doi.org/10.12973/eurasia.2017.00641a.

[16] Asio, J.M.R., \& Riego de Dios, E.E. (2018). $21^{\text {st }}$-century attributes and skills of a teacher from the perspective of college students. https://doi.org/10.6084/m9.figshare.12722171.v1.

[17] Asio, J.M.R., \& Riego de Dios, E.E. (2019). The college students' perspective on what makes an educator well-qualified. Journal of Pedagogical Research, 3 (3), 126-138. https://dx.doi.org/10.33902/jpr.v3i3.124.

[18] Arnold, N., \& Ducate, L. (2015). Contextualized views of practices and competencies in CALL teacher education research. Language Learning \& Technology, 19(1), 1-9. http://1lt.msu.edu/issues/february2015/commentary.pdf.

[19] Asio, J.M.R., \& Jimenez, E.C. (2020). Effect of remediation activities on grade 5 pupils' academic performance in Technology and Livelihood Education (TLE). Pedagogical Research, 5(4), em0075. https://doi.org/10.29333/pr/8464.

[20] Torres, M.R.M., Marín, S.L.T., García, F.B., Vázquez, S.G., Oliva, M.A., \& Torres, T. (2008) A technological acceptance of e-learning tools used in practical and laboratory teaching, according to the European higher education area. Behaviour \& Information Technology, 27:6, 495-505. https://doi.org/10.1080/01449290600958965.

[21] Al-Hilli, W. H. (2018). Using software and technology in solving Mathematics problems to motivate and accelerate the learning process. EURASIA Journal of Mathematics, Science and Technology Education, 15(3), em1670, https://doi.org/10.29333/ejmste/102421.

[22] Teo, T.S.H., Kim, S.L., \& Jiang, L. (2020). E-learning implementation in South Korea: Integrating effectiveness and legitimacy perspectives. Information System Frontiers, 22 511-528. https://doi.org/10.1007/s10796-018-9874-3. 